\title{
Domagoj Tomas
}

(Filozofski fakultet, Sveučilište u Osijeku)

\section{PODODBOR MATICE HRVATSKE U OSIJEKU 1936. - 1945.}

UDK 061.22(497.5 Osijek)“1936/1945“

Pregledni rad

Primljeno: 27. 12. 2018.

\begin{abstract}
U članku se opisuju i razlažu nastanak i djelovanje Pododbora Matice hrvatske u Osijeku od njegova osnutka 1936. do prisilnoga gašenja 1945 ., uzimajući u obzir da su ranije objavljene pregledne sinteze djelovanja Matice hrvatske u Osijeku izostavile to razdoblje iz svoga fokusa, držeći 1961. godinom prvoga osnutka Matičina pododbora (ogranka) u Osijeku. Analiza ima uporište u metodološkoj paradigmi intelektualne povijesti, s kontekstualizacijom protagonista i aktivnosti osječkoga Pododbora Matice hrvatske u široj intelektualnoj mreži grada Osijeka, organizacijske strukture Matice hrvatske i srodnih društava unutar društveno-političke zbilje u Kraljevini Jugoslaviji i Nezavisnoj Državi Hrvatskoj te intelektualnih gibanja unutar europskoga prostora toga vremena. Zbog nedostatne količine izvorne građe za kasnije referentno razdoblje, ponajviše prostora zauzima raščlamba prvih dviju godina djelovanja Pododbora Matice hrvatske u Osijeku, dok se nedostatak izvora za razdoblje Nezavisne Države Hrvatske pokušava supstituirati analizom časopisa Hrvatski sjever iz 1944.
\end{abstract}

Ključne riječi: Matica hrvatska, pododbor, Osijek, Kraljevina Jugoslavija, Nezavisna Država Hrvatska, Hrvatski sjever (časopis)

\section{Uvodne napomene}

Matica hrvatska ${ }^{1}$ (dalje: MH), kao najstarija djelatna hrvatska kulturna institucija, često je bila predmetom povijesno-publicističkih tek-

\footnotetext{
${ }^{1}$ Matica hrvatska osnovana je 1842. pod nazivom Matica ilirska (naziv Matica hrvatska nosi od 1874.), sa svrhom promicanja nacionalnoga i kulturnoga identiteta u područjima umjetničkog, znanstvenog i duhovnog stvaralaštva, gospodarstva i javnoga života te skrbi za društveni razvitak. Trenutno objavljuje dvotjednik Vijenac, književni list za umjetnost, kulturu i znanost, Hrvatsku reviju, časopis za književnost, umjetnost i kulturu življenja, te književni i znanstveni časopis Kolo. Jedna je od institucija koje su uvelike oblikovale modernu hrvatsku naciju.
} 
stova i publikacija, ${ }^{2}$ ali i istinskih historiografskih studija. ${ }^{3}$ Također, $\mathrm{u}$ određenim je okolnostima uslijed svoga društvenog aktivizma postajala predmetom političko-obavještajne obrade, koja je znala dovesti do zabrane njezina djelovanja, o čemu su kasnije isto tako publicirane zbirke dokumenata. ${ }^{4}$

Osječki ogranak ${ }^{5} \mathrm{MH}$ također je bio predmetom povijesno-publicističkih analiza ${ }^{6}$ te svojevrsnih antologija i preglednih sinteza publicističke aktivnosti, ${ }^{7}$ no njegova djelatnost između 1936. i 1945. još je uvijek ostala historiografski potpuno neobrađena, iz čega se ukazala potreba za ovim člankom, utemeljenim na izvornoj građi, dostupnoj u Državnom arhivu u Osijeku (dalje: DAOS), $\mathrm{u}$ fondu Pododbor Matice hrvatske Osijek. Djelatnost pododbora moguće je pratiti i analizirati putem zapisnika sa sjednica te ponekih dopisa prema središnjici MH u Zagrebu i obrnuto. Nažalost, ta je građa uglavnom ograničena na djelovanje osječkoga pododbora MH 1936. - 1937., dok je građa iz kasnijega referentnog razdoblja vrlo fragmentarna, odnosno svodi se na jedan jedini dokument iz 1944. Stoga je potrebno koristiti i sekundarnu građu, preko koje se posredno mogu utvrditi neke osnovne činjenice te donekle raščlaniti i aktivnosti osječkoga pododbora $\mathrm{MH}$, poput časopisa Hrvatski sjever, ${ }^{8}$ koji je 1944. objavljen upravo u izdanju osječkoga pododbora MH.

Kada je riječ o dosadašnjim istraživanjima djelovanja MH u Osijeku, nezaobilazna je studija Dragana Mucića pod nazivom Matica hrvatska u Osijeku 1960 - 1970. Riječ je o vrlo opsežnom, informativnom i korisnom povijesnopublicističkom pregledu aktivnosti Pododbora/Ogranka MH Osijek između

${ }^{2}$ O Matici hrvatskoj prigodom njezinih velikih obljetnica na nacionalnoj razini pisali su njezini predsjednici Jakša Ravlić, Josip Bratulić i Stjepan Damjanović. Više: Jakša Ravlić, Matica hrvatska: 1842-1962 (Zagreb, 1963); Josip Bratulić, Matica hrvatska: 1842-1997 (Zagreb, 1997); Stjepan Damjanović, Matica hrvatska od 1842. do 2017. Kalendar rada i djelovanja (Zagreb, 2018). Također, mnogi su autori pisali o povijesti pojedinih ogranaka prigodom obljetnica njihova osnutka ili obnove rada.

${ }^{3}$ Višeslav Aralica, Matica hrvatska u Nezavisnoj Državi Hrvatskoj (Zagreb, 2009).

${ }^{4}$ Jelena Hekman, Izvještaj o kontroli zakonitosti rada Matice hrvatske (Zagreb, 1972).

${ }^{5}$ Ovdje se za temeljnu organizacijsku jedinicu MH rabi aktualni naziv „ogranak“, dok će se kasnije u članku rabiti njezin stariji naziv ,pododbor“, sukladno njegovoj uporabi u razdoblju između 1936. i 1945. Prema izvornoj građi iz DAOS-a, naziv ,pododbor“ zamijenjen je nazivom „ogranak“ tijekom 60-ih godina 20. st.

${ }^{6}$ Dragan Mucić, Matica hrvatska u Osijeku 1960 - 1970. (Osijek, 1971).

${ }^{7}$ Helena Sablić Tomić, Goran Rem, Sretne ulice: osječka čitanka (Osijek, 2001; pretisak 2017); Mirta Bijuković, Katica Delač, Valentina Majdenić (ur.), Matica hrvatska ogranak Osijekdokumentarij 2003.-2007. (Osijek, 2007); Igor Gajin, Tatjana Ileš, Ivan Trojan, Osijek 2.0. osječka čitanka II (Osijek, 2017).

${ }^{8}$ Hrvatski sjever, časopis Pododbora MH Osijek. Uz Hrvatsku misao, časopis Pododbora MH Sarajevo, jedini časopis MH koji je u vrijeme Nezavisne Države Hrvatske izlazio izvan Zagreba. 
1960. ${ }^{9}$ i 1970. Naravno, tu je i hrestomatija osječke književnosti pod nazivom Osječka čitanka. Sretne ulice iz 2001. te njezino drugo i dopunjeno dvotomno izdanje iz 2017., kao panoramski prikaz starije, novije i recentne osječke književne produkcije, u kojoj prednjači osječki ogranak MH. Na nacionalnoj pak razini, djelatnost $\mathrm{MH}$ opisivana je u djelima koja su kao predsjednici $\mathrm{MH}$ priređivali Jakša Ravlić, Josip Bratulić i Stjepan Damjanović, a vrijedan doprinos u tom smislu dao je i Stjepan Sučić, dugogodišnji potpredsjednik MH, koncentrirajući se na pregled rada njezinih ogranaka. ${ }^{10}$ Svakako valja istaknuti i historiografsku studiju Višeslava Aralice o MH u Nezavisnoj Državi Hrvatskoj (dalje: NDH) te zbirku objavljenih dokumenata o aktivnostima MH koji su nastali neposredno nakon burne 1971. i događaja poznatih pod zajedničkim nazivnikom Hrvatskoga proljeća, a objavljeni su 2002.

MH, dakle, svakako predstavlja najstariju djelatnu i jednu od stožernih hrvatskih kulturnih institucija uopće, čije su aktivnosti ponajviše oblikovali njezini visokoobrazovani članovi, od kojih su mnogi ujedno bili i vodeći intelektualci svoga vremena. Naravno, sustav MH unutar kojega su oni djelovali isto je tako oblikovao njihove intelektualne profile pa možemo reći da je taj utjecaj bio dvosmjeran. Osim toga, aktivnosti MH i djelovanje njezinih protagonista korespondiralo je s dinamičnim duhovno-intelektualnim gibanjima unutar matičnih društveno-političkih okvira, ali i širih europskih horizonata, posebice u referentnom međuratnom razdoblju, a donekle i u vrijeme globalnoga kaosa Drugoga svjetskog rata.

Stoga se najprikladnijim teorijsko-metodološkim polazištem za analizu djelovanja $\mathrm{MH}$, pa tako i njezinih pojedinačnih ogranaka, čini intelektualna povijest, ${ }^{11}$ koja u fokus stavlja analizu mišljenja i ideja kao instrumenata kolektivnog djelovanja u javnom životu. Taj se pristup razvio u drugoj polovici 20. st., ponajviše na angloameričkom i francuskom području, gdje su se ujedno isprofilirala dva derivata toga modela. Angloamerička škola intelektualne povijesti tako naglasak stavlja na analizu društvene uloge i aktivnosti individualnih protagonista promatranih idejno-svjetonazorskih obrazaca, dok je francuska škola usmjerena na organizirane društvene skupine i neformalne intelektualne mreže, koje mogu biti nacionalne ili transnacionalne. Kombiniranjem tih dviju historiografskih tradicija moguće je prezentirati slojevitiju sliku složenih sociokulturnih i političkih procesa koji su obilježili razdoblje prve polovice 20. st.

\footnotetext{
${ }^{9}$ Pododbor MH Osijek ponovno je osnovan pod tim nazivom 1961., no već su 1960. započele aktivnosti oko njegova osnutka, dok je kasnije tijekom 60-ih iz uporabe izbačen naziv „pododbor“, a uveden „ogranak“, o čemu svjedoče razni službeni dokumenti te sam pečat Pododbora/Ogranka MH Osijek.

${ }^{10}$ Stjepan Sučić, „Ogranci kao žile kucavice Matice hrvatske“, Kolo XXVII (2017), br. 3, 116-134.

${ }^{11}$ Neki će prije upotrijebiti također legitiman termin intelektualna historija.
} 


\section{Povjereništvo Matice hrvatske u Valpovu}

Podatke o djelovanju MH na širem osječkom području moguće je pronaći u DAO. Naime, postojanje fonda pod nazivom Pododbor Matice hrvatske Valpovo, ${ }^{12} \mathrm{~s}$ pripadajućom građom, svjedoči o aktivnostima $\mathrm{MH}$ na području istočne Slavonije i Baranje i prije nastanka osječkoga pododbora MH. Tako je ondje moguće analizirati aktivnosti povjerenika MH na valpovačkom području još tijekom posljednjih dvaju desetljeća 19. st. te u prvom desetljeću 20. st. Sve u svemu, te su se aktivnosti uglavnom svodile na agitacije prema potencijalnom članstvu, odnosno upisivanje novih članova te distribuciju tiskanih izdanja $\mathrm{MH}$, kao i jačanje i učvršćivanje hrvatskoga nacionalnog identiteta kod širih slojeva stanovništva.

Na temelju nekih dokumenata, poput upisnih araka članova za valpovačko povjereničko okružje, moguće je izvršiti prilično dobru analizu kretanja broja članova između 1884. i 1910. U tom su razdoblju dužnost povjerenika MH u Valpovu obavljali Luka Ćosić, vlastelinski pristav ${ }^{13}$ kod NormannEhrenfelsa, ${ }^{14}$ i Stjepan pl. Hankonyi, nadšumar.

Tablica 1. Povjerenici MH u Valpovu i članstvo na valpovačkom povjereničkom području po godinama

\begin{tabular}{|l|l|l|}
\hline Godina & Broj članova & Povjerenik \\
\hline 1884. & 33 & Luka Ćosić \\
\hline 1886. & 32 & Luka Ćosić \\
\hline 1888. & 32 & Luka Ćosić \\
\hline 1889. & 25 & Luka Ćosić \\
\hline 1890. & 28 & Luka Ćosić \\
\hline 1892. & 43 & nije naveden \\
\hline 1893. & 46 & Stjepan pl. Hankonyi \\
\hline 1902. & 38 & Stjepan pl. Hankonyi \\
\hline 1907. & 25 & Stjepan pl. Hankonyi \\
\hline 1910. & 20 & Stjepan pl. Hankonyi \\
\hline
\end{tabular}

${ }^{12}$ Fond se naziva Pododbor Matice hrvatske Valpovo, premda zapravo nije riječ o sačuvanoj građi pododbora, koji u Valpovu nije niti postojao u vrijeme nastanka građe, već o povjereništvu, o čemu će biti riječi kasnije.

${ }^{13}$ Pristav, starohrvatski naziv za činovnika koji je obavljao razne poslove, uglavnom upravne i sudske naravi.

${ }^{14}$ Obitelj Normann-Ehrenfels upravlja valpovačkim vlastelinstvom od 1885., kada umire Gustav Hilleprand von Prandau, a posjed nasljeđuje njegova kći Marijana, odnosno njezini sinovi Rudolf i Gustav Normann-Ehrenfels. 
Teritorijalna struktura članstva također se može iščitati iz istih dokumenata. Premda prednjači Valpovo, članstva je bilo i u manjim sredinama, poput Petrijevaca, Harkanovaca, Veliškovaca, Bizovca, Koške, Bocanjevaca, Ivanovaca i Belišća.

Podatci o profesionalnoj strukturi članstva isto su tako dostupni u spomenutim dokumentima, a dominiraju vlastelinski i općinski činovnici, svećenstvo (dekani, župnici i kapelani), učitelji, šumari te poneki trgovac i ljekarnik.

Treba napomenuti da su tada u MH bila moguća dva oblika članstva, i to individualno (osobno) i skupno (institucionalno), što je uključivalo škole, čitaonice i sl.

Iz toga razdoblja posebno vrijedi izdvojiti zanimljivo i indikativno pismo Antala Patakija, župnika u Olaszu, ${ }^{15}$ u kojem se 7. kolovoza 1889., na tečnom hrvatskom jeziku, zahvaljuje Luki Ćosiću, povjereniku MH za valpovačko „povjereničko okružje“, na primjercima knjiga u izdanju MH koji su mu poslani. Osim toga, Pataki se na kraju pisma, ispod pečata sa svojim imenom i župničkom titulom na mađarskom jeziku (mađ. $r$. $k$. áldozár), vlastoručno potpisao kao član MH. ${ }^{16}$ Dakle, to je pismo još jedan u nizu priloga koji dekonstruiraju pojednostavljen, ali proširen narativ o nepovjerenju i međunacionalnoj netrpeljivosti između Hrvata i Mađara u 19. st., ${ }^{17}$ posebice jer se radi o razdoblju banovanja Károlya Khuen-Héderváryja, koje je s hrvatske strane najčešće karakterizirano kao vrhunac mađarizacije, dok Khuen-Héderváry i danas personificira taj proces. Patakijevo pismo svjedoči o tome da je na društvenom i kulturnom planu među nositeljima nacionalnoga i religijskoga identiteta na lokalnoj razini na objema stranama postojala intenzivna komunikacija i bogata suradnja, bez obzira na eventualne nesuglasice u političkom životu, te da nije bilo strano da se župnik s područja Ugarske aktivira u radu $\mathrm{MH}$, a uz to i tečno govori hrvatski jezik. Isto tako, poznavanje mađarskoga jezika među župnicima na području Hrvatske i Slavonije te posebice južnoga dijela Baranje nakon 1920. bilo je posve uobičajena pojava u mikrosredinama gdje je bio znatniji udio mađarskoga stanovništva. ${ }^{18}$

${ }^{15}$ Olasz, mjesto u Baranji (Mađarska), nedaleko od Pečuha.

${ }^{16}$ Državni arhiv u Osijeku, fond Pododbora Matice hrvatske Valpovo (dalje: HR-DAOS-1414), kut. 1, Pismo Antala Patakija Luki Ćosiću, 7. kolovoza 1889.

${ }^{17}$ Tom se problematikom u svojim historiografskim studijama zadnjih godina bavio i Dinko Šokčević. Vidi: Dinko Šokčević, Hrvati u očima Mađara, Mađari u očima Hrvata: kako se u pogledu preko Drave mijenjala slika drugoga (Zagreb, 2006).

${ }^{18}$ Više: Domagoj Tomas, Apostolska administratura za sjevernu Slavoniju i Baranju (1923. 1972.) (Đakovo - Osijek, 2018), 81-97. 


\section{Nastanak i djelovanje Pododbora Matice hrvatske u Osijeku}

U drugoj polovici 30-ih i prvoj polovici 40-ih godina 20. st. MH se posvetila intenzivnijem radu oko osnivanja i širenja mreže svojih pododbora. Poseban poticaj tim aktivnostima dao je zaključak s Glavne godišnje skupštine $\mathrm{MH}$, održane 15. prosinca 1935., povodom proslave 100. obljetnice hrvatskoga narodnog preporoda. Tada je istaknuta potreba reorganizacije i obnove te osnivanja novih pododbora u predstojećem razdoblju, i to u svakom znatnijem hrvatskom mjestu. ${ }^{19}$ Na tragu toga zaključka pristupilo se i osnivanju Pododbora MH u Osijeku 1936., a iste godine osnovani su građanski, ženski i sveučilišni pododbor u Zagrebu te pododbori u Čakovcu, Sisku, Karlovcu, Samoboru, Sušaku i Varaždinu. ${ }^{20}$

Već 20. ožujka 1936., u jeku predradnji za osnutak Pododbora MH u Osijeku, Franji Helfrichu, ${ }^{21}$ povjereniku MH u Osijeku, stigao je dopis iz središnjice MH u Zagrebu, potpisan od strane Filipa Lukasa, ${ }^{22}$ predsjednika MH, i Mile Starčevića. ${ }^{23} \mathrm{U}$ njemu se izražava zadovoljstvo obavljenim pripremama te se Helfrichu i novinaru Matiji Kovačiću ${ }^{24}$ nalaže da sastanak najave političkoj vlasti. Uz to, priložena su pravila MH te je najavljen Starčevićev dolazak na konstituirajuću

${ }^{19}$ Sučić, „Ogranci kao žile kucavice Matice hrvatske“, 116.

${ }^{20}$ Damjanović, Matica hrvatska od 1842. do 2017., 135.

${ }^{21}$ Franjo Helfrich (1904. - 1981.), ljekarnik. Aktivan u društvenom i kulturnom životu Osijeka između dvaju svjetskih ratova kroz članstva i dužnosti u raznim organizacijama; donjogradskom Hrvatskom sokolu, Pododboru Matice hrvatske u Osijeku, Hrvatskom junaku i dr. Njegovu obiteljsku kuću, uglovnicu na raskrižju današnje Vukovarske ulice i Ulice Otokara Keršovanija, projektirao je 1939. Ljudevit Pelzer, najznačajniji arhitekt osječke moderne. Prema tvrdnjama pranećakinje Mirte Galo, u vrijeme NDH imenovan je na mjesto dogradonačenika Osijeka 1942. Vidi: Barbara Vuković, „Kako preživjeti smjenu režima? Sudbina Folksdojčera na prostoru Hrvatske“, Lucius 14 (2016), 21, 183.

${ }^{22}$ Filip Lukas (1871. - 1958.), geograf, povjesničar i teolog. Od 1919. do 1945. predavao je ekonomsku geografiju na Ekonomsko-komercijalnoj visokoj školi u Zagrebu, a od 1928. do 1945. bio je predsjednik Matice hrvatske. U tridesetim godinama 20. st. slovio kao jedan od vodećih hrvatskih intelektualaca nacionalističke orijentacije, a za vrijeme NDH u nekim se aspektima distancirao od ustaške politike. U svibnju 1945. otišao u iseljeništvo te najprije živio u Klagenfurtu, a zatim do smrti u Rimu.

${ }^{23}$ Mile Starčević (1904. - 1953.), kulturni djelatnik i političar. Diplomirao filozofiju na Filozofskom fakultetu u Zagrebu, gdje je i doktorirao 1932. Kao član uprave MH aktivno poticao nastanak njezinih pododbora 30-ih godina 20. st. Uređivao je časopise Hrvatska mladica, Nastavni vjesnik i Omladina. Prvotno član Hrvatske federalističke seljačke stranke, a kasnije se priključuje ustaškom pokretu. Za vrijeme NDH obavlja dužnost ministra narodne prosvjete 1942. - 1943. te ravnatelja i urednika tjednika Seljačko ognjište 1942. - 1945. Nakon sloma NDH povlači se u Austriju i Italiju te se 1947. trajno nastanjuje u Argentini.

${ }^{24}$ Matija Kovačić (1901. - 1972.), novinar. Urednik politike u osječkom Hrvatskom listu od 1929. do 1941. Urednik je Hrvatskoga naroda 1941. - 1942., a potom savjetnik u Ministarstvu vanjskih poslova NDH. Od listopada 1942. do siječnja 1944. glavni je ravnatelj Glavnoga ravnateljstva za promidžbu. Nakon sloma NDH u svibnju 1945. odlazi u iseljeništvo, gdje objavljuje memoare Od Radića do Pavelića 1970. Vidi: Tko je tko u NDH (Zagreb, 1997), 201-202. Ante Ciliga svrstava ga 
skupštinu. ${ }^{25}$ Slijedom toga, gradska policija obaviještena je 21. ožujka 1936. o skorom održavanju konstituirajuće skupštine osječkoga pododbora MH. ${ }^{26}$

Osječki pododbor MH svoju je konstituirajuću skupštinu imao 29. ožujka 1936. u prostorijama Hrvatskoga doma ${ }^{27} \mathrm{u}$ Gornjem gradu, a kao izaslanik MH iz Zagreba prisustvovao je Mile Starčević. Iz Osijeka su bili prisutni Aleksandar Hećimović ${ }^{28}$ i Franjo Helfrich, kao povjerenici MH u Osijeku, zatim Matija Kovačić, kao sazivač skupštine, te brojni drugi članovi MH. Izaslanik Starčević pritom je održao predavanje pod naslovom „O značenju $\mathrm{MH}$ u prošlosti i sadašnjosti hrvatskog naroda“, a jednoglasno su izabrani svi dužnosnici, odnosno tijela Pododbora MH Osijek. Na mjesto predsjednika izabran je Tomislav Pavetić, ${ }^{29}$ na mjesto potpredsjednika Aleksandar Hećimović, na mjesto tajnika Franjo Helfrich te na mjesto blagajnika Vatroslav Kozmar. ${ }^{30}$ Za pročelnika literarne sekcije izabran je Matija Kovačić, dok je za pročelnika propagandne sekcije izabran Josip Pavišić. Na mjesto članova odbornika izabrani su Ivan Aničić, Milan Blažeković, ${ }^{31}$

u jednu od četiriju ,anglofilskih“ struja u ratnom Zagrebu 1941. - 1945. Vidi: Stipe Kljaić, Nikada više Jugoslavija. Intelektualci i hrvatsko nacionalno pitanje (1929. - 1945.) (Zagreb, 2017), 41.

${ }^{25}$ Državni arhiv u Osijeku, fond Pododbora Matice hrvatske Osijek (dalje: HR-DAOS-939), kut. 1, Dopis Filipa Lukasa Franji Helfrichu, 20. ožujka 1936.

${ }^{26}$ HR-DAOS-939, kut. 1, Dopis Pododbora Matice hrvatske u Osijeku gradskoj policiji, 21. ožujka 1936.

${ }^{27}$ Hrvatski dom u osječkom Gornjem gradu nalazio se na današnjoj adresi Ulica Stjepana Radića 20, u zgradi koju je do 2009. koristila Ugostiteljsko-turistička škola. Njegova je osnovna funkcija bila osigurati prostor za djelovanje svim osječkim društvima s hrvatskim predznakom.

${ }^{28}$ Aleksandar Hećimović (? - 1939.), pravnik. Do zabrane 1929. jedan od vodećih ljudi Hrvatske stranke prava u Osijeku.

${ }^{29}$ Tomislav Pavetić (1892. - 1940.), gimnazijski profesor. U Beču 1913. počeo studirati veterinu, ali ju je napustio i završio studij kemije i prirodopisa na Filozofskom fakultetu u Zagrebu. Do kolovoza 1927. službovao u Slavonskom Brodu, a s izborom za predsjednika Oblasne skupštine prešao je u Osijek, gdje je do samoubojstva radio kao profesor na realnoj gimnaziji. Vidi: Mira Kolar-Dimitrijević, „Ukinuće Bjelovarsko-križevačke županije i kako je to područje prošlo u vrijeme djelovanja Osječke i Zagrebačke oblasne skupštine 1927. i 1928. godine“, Radovi Zavoda za znanstvenoistraživački i umjetnički rad u Bjelovaru 2 (2008), 40. Mira Kolar-Dimitrijević u svom članku navodi da je Pavetić umro, počinivši samoubojstvo 1930., no godina njegove smrti definitivno je 1940., što je utvrđeno tijekom istraživanja za potrebe ovoga članka.

${ }^{30}$ Vatroslav Kozmar, sudjelovao u Prvom svjetskom ratu, do 1945. vodio Odjel financija Gradskog poglavarstva u Osijeku.

${ }^{31}$ Milan Blažeković (1878. - 1946.), od 1902. do 1924. radio u političko-upravnoj službi bosanskohercegovačke uprave, a u Osijek dolazi 1924. Bio je tajnik Prvoga hrvatsko-slavonskog d. d. za industriju šećera, istaknuti privrednik i član mnogobrojnih kulturnih udruga te predsjednik Arheološkog kluba „Mursa“ od 1934. do 1945. Za vrijeme NDH imenovan je logornikom te je kratko razdoblje (svibanj - lipanj 1941.) bio osječki gradonačelnik. U 


\begin{abstract}
Nikola Butković, Milan Čačinović, ${ }^{32}$ Dragutin Engelhardt, Stjepan Hefer, ${ }^{33}$ Ferdo Kornburger, Slavko Kovačević, Karlo Köhler, ${ }^{34}$ Kamilo Krvarić, ${ }^{35}$ Josip Lakšteter, Franjo Lukac, ${ }^{36}$ Josipa Glembay, ${ }^{37}$ Vladimir Mrljak i Lavoslav Rohregger, dok su u nadzorni odbor ušli Kamilo Firinger, ${ }^{38}$ Dragutin Škuljević i Ljudevit Vice. ${ }^{39}$
\end{abstract}

kolovozu 1945. u Osijeku je osuđen na 15 godina robije s prisilnim radom. Umro je u logoru Stara Gradiška. Vidi: Tko je tko u NDH, 40-41.

${ }^{32}$ Milan Čačinović, stomatolog. Aktivan u nizu kulturnih i potpornih društava u Osijeku između dvaju svjetskih ratova. Predsjednik Filharmonijskoga društva, osnovanoga 1924., predsjednik Rotary kluba Osijek 1940. - 1941.

${ }^{33}$ Stjepan Hefer (1897. - 1973.), odvjetnik i političar. Gimnaziju završio u Osijeku, a studij prava u Zagrebu, gdje je i doktorirao 1920. Vrlo aktivan u kulturnom i političkom životu, istaknuti član Hrvatske seljačke stranke, na izborima 1935. i 1938. biran za narodnoga zastupnika kotara Valpovo. Nakon proglašenja NDH postaje veliki župan Velike župe Baranja sa sjedištem u Osijeku, a od veljače 1942. član je Hrvatskoga državnog sabora. Od listopada 1943. do svibnja 1945. ministar seljačkoga gospodarstva i prehrane, a nakon sloma NDH odlazi u iseljeništvo te se trajno nastanjuje u Argentini. Ante Pavelić u svojoj ga je oporuci 1959. odredio za opunomoćenoga nasljednika na mjestu čelnika Hrvatskoga oslobodilačkog pokreta.

${ }^{34}$ Karlo Köhler, inženjer kemije. Zaposlen u osječkoj Šećerani, redovni član Jugoslavenskoga hemijskog društva u Zagrebu, predsjednik osječke podružnice HKD Napredak za vrijeme NDH.

${ }^{35}$ Kamilo Krvarić (1894. - 1958.), novinar. Novinarstvom se bavi od 1929., suvlasnik i ravnatelj Hrvatskog lista u Osijeku. Za vrijeme NDH stožernik ustaškog stožera za Veliku župu Baranja u Osijeku, a u veljači 1944. imenovan povjerenikom u Glavnom ustaškom stanu za vezu s njemačkim vlastima. Nakon sloma NDH 1945. odlazi u iseljeništvo te se trajno nastanjuje u Argentini. Amaterski se bavio slikarstvom.

${ }^{36}$ Franjo Lukac (1894. - 1946.), službovao u austrougarskoj vojsci, vojnu službu nastavio i u Kraljevini SHS, ali je umirovljen 1929. Pred propast Kraljevine Jugoslavije optužen da je član ustaškog pokreta, ali je oslobođen zbog nedostatka dokaza. Poslije uspostave NDH ustaški je povjerenik i organizator vlasti u Osijeku i okolini. Krajem lipnja 1941. postavljen je za glavara Glavnoga stožera Ustaške vojnice i unaprijeđen u čin ustaškoga pukovnika. Početkom studenoga 1941. imenovan zapovjednikom redarstvene straže za cjelokupno područje NDH pri Ravnateljstvu za javni red i sigurnost i na toj dužnosti ostaje do rujna 1942. U srpnju 1942. imenovan zapovjednikom redarstvene straže u Ustaškoj vojnici, a u veljači 1944. hrvatski je izaslanik kod 373. legionarske divizije. Nakon sloma NDH uhićen je i osuđen na smrt 1946.

37 Josipa Glembay (1861. - 1941.), jedina ženska članica odbornica Pododbora MH u Osijeku i dugogodišnja predsjednica društva Hrvatska žena u Osijeku (1921. - 1941.), o čijem bi se životu i djelu mogao napisati zaseban članak, a vjerojatno i opsežnija studija.

${ }^{38}$ Kamilo Firinger (1893. - 1984.), studij prava s doktoratom završio 1921. Sudjelovao u Prvom svjetskom ratu. Odvjetnik u Osijeku 1922. - 1946. Tijekom Drugoga svjetskog rata domobran, potkraj rata surađivao s partizanima. Nakon 1945. kratko radio u osječkome Gradskom muzeju, a 1947. imenovan upraviteljem ispostave zagrebačkoga Državnog arhiva u Osijeku. Njegovom zaslugom utemeljen je 1956. Historijski arhiv u Osijeku, kojemu je ravnatelj bio do umirovljenja 1977.

${ }^{39}$ HR-DAOS-939, kut. 1, Zapisnik s konstituirajuće skupštine Pododbora Matice hrvatske u Osijeku, 29. ožujka 1936., 1-2. 
Prva sjednica predsjedničkoga vijeća ${ }^{40}$ osječkoga pododbora MH održana je 6. travnja 1936. u prostoriji Hrvatske građanske čitaonice u gornjogradskom Hrvatskom domu. Prisutni su bili svi članovi predsjedničkoga vijeća, s izuzetkom Pavišića, a zaključeno je da sva predavanja u njihovoj organizaciji trebaju biti „nacionalnoga karaktera“ te obrađivati teme „,iz hrvatskog narodnog života“. ${ }^{41}$ Prvo takvo predavanje zakazano je za 18. travnja 1936. u $20.30 \mathrm{~h}$ u gornjogradskom Hrvatskom domu, s prijedlogom da Hefer zamoli Rudolfa Hercega ${ }^{42}$ da održi predavanje o hrvatskom seljačkom pokretu, što ne čudi, s obzirom na to da su i Hefer i Herceg bili istaknuti pripadnici Hrvatske seljačke stranke (dalje: HSS). Također, odlučeno je da Pavetić i Kovačić do sljedeće sjednice sastave popis od deset tematskih predavanja, koja bi onda održali osječki i zagrebački javni radnici. Usvojen je i Kovačićev prijedlog da se uputi dopis predsjedniku MH Lukasu, s namjerom da Hrvatski list ${ }^{43}$ donese recenziju svake knjige koju MH objavi, no ona pritom ne bi smjela biti „stroga kritička ocjena djela“, već imati više „propagandni karakter“. ${ }^{44}$ Iz toga je jasno vidljivo na koji je način MH koristila mogućnost propagande putem utjecajnoga dnevnog tiska. Na koncu je zaključeno da bi se sjednice predsjedničkoga vijeća trebale održavati svakih 14 dana, a proširenoga pododbora prema potrebi.

U listopadu 1936. osječki pododbor MH uputio je predsjedniku Lukasu dopis u kojem mu predlaže da u Osijeku održi predavanje s temom po vlastitom izboru, kao prvo u nizu u ciklusu najavljenih predavanja ${ }^{45} \mathrm{Iz}$ tog je dopisa jasno da se komunikacija po tom pitanju između osječke MH i zagrebačke sre-

${ }^{40}$ Predsjedničko vijeće obuhvaćalo je predsjednika, potpredsjednika, tajnika, blagajnika te pročelnike sekcija.

${ }^{41}$ HR-DAOS-939, kut. 1, Zapisnik I. sjednice predsjedničkoga vijeća Pododbora Matice hrvatske u Osijeku, 6. travnja 1936., 1.

${ }^{42}$ Rudolf Herceg (1887. - 1951.), hrvatski političar i javni djelatnik. Član Glavnoga odbora Hrvatske (republikanske) seljačke stranke te zastupnik na skupštinskim izborima 1920. i 1923. Od 1925. posvetio se kulturno-prosvjetnom radu, pokretač, tajnik i glavni promicatelj rada Seljačke sloge 1925. - 1929., njezin predsjednik 1935. - 1941. te urednik njezina glasila Seljačka prosvjeta 1926. - 1929. S javnim radom prestao 1941., uhićen 1949., bez presude zadržan u logoru do 1951., kada je pušten teško bolestan.

${ }^{43}$ Hrvatski list, najutjecajnije osječke dnevne novine koje su izlazile u razdoblju 1920. - 1945. U početku kao glasilo Hrvatske zajednice, kasnije se približavaju stavovima ustaškoga pokreta, a u vrijeme NDH djeluju kao jedine privatne novine. Nakon 1945. zabranjeno im je izlaženje.

${ }^{44}$ HR-DAOS-939, kut. 1, Zapisnik I. sjednice predsjedničkoga vijeća Pododbora Matice hrvatske u Osijeku, 6. travnja 1936., 2.

${ }^{45}$ Iz sadržaja ovoga dopisa dalo bi se zaključiti da do tada nije realizirana ranije najavljena mogućnost predavanja Rudolfa Hercega u Osijeku. 
dišnjice, odnosno Starčevića, odvijala i ranije iste godine, u travnju i svibnju, a na ovaj dopis potpis su stavili predsjednik Pavetić i tajnik Helfrich. ${ }^{46}$

Izvanredna sjednica Pododbora MH Osijek, povodom Lukasova predavanja, održana je 14. studenoga 1936. u prostorijama Hrvatske žene ${ }^{47}$ u gornjogradskom Hrvatskom domu. Kako je sjednica održana nakon Lukasova predavanja („O razvoju nacionalne misli kod Hrvata“), prisustvovao joj je i sam Lukas, a Pavetić je upozorio na problematične okolnosti u kojima su se našle sve hrvatske kulturne institucije nakon 1929., pa tako i MH. Prisutnima se nakon Pavetića obratio i Lukas, zahvalivši se te obećavši da će sljedećega proljeća u Osijeku ponovno nastojati održati predavanje („O Irskoj“).$^{48}$

Pododbor MH Osijek intenzivno je kontaktirao i surađivao s drugim srodnim društvima u domeni kulture, o čemu svjedoči ne samo sastav njegove uprave, već i dopis Hrvatskoga akademskog kulturnog društva Ante Starčević (dalje: HAKD Ante Starčević) u Osijeku upućen 9. siječnja 1937., u kojem je osječki pododbor MH obaviješten o osnutku toga društva. ${ }^{49}$

Posebno je zanimljiv dopis koji je član odbornik Franjo Lukac 16. veljače 1937. uputio predsjedniku osječkoga pododbora MH. Naime, Lukac traži brisanje iz članstva, uz obrazloženje da ne može podržati zaključak izaslanika hrvatskih kulturnih društava, kojemu se pridružila i $\mathrm{MH}$, ,pod pritiskom jednog člana vodstva b.H.S.S.“. Tim se činom MH, prema njegovu mišljenju, stavila ,pod okrilje jedne političke grupe, koja na odgovornim mjestima podržaje elemente, koji nemaju ništa zajedničkog sa hrvatskim narodnim pokretom“. Također, Lukac je naveo i prigovor na sastav osječkoga pododbora $\mathrm{MH}$, ističući da se ondje nalaze „i ljudi, koji igraju razne uloge, te se dapače iz materijalnih razloga i obaraju na hrvatske nacionalne borce“ ${ }^{50}$ Nažalost, Lukac ne navodi izrijekom o kome se zapravo radi pa je teško izvoditi daljnje interpretacije po tom pitanju. Međutim, njegov zahtjev valja smjestiti u

${ }^{46}$ HR-DAOS-939, kut. 1, Dopis Pododbora Matice hrvatske u Osijeku Filipu Lukasu, 12. listopada 1936.

${ }^{47}$ Više o djelovanju udruge Hrvatska žena u Osijeku: Ivana Lončar, „Udruga Hrvatska žena u Osijeku (1921. - 1943.)“, Scrinia Slavonica 11 (2011), 207-258.

${ }^{48}$ HR-DAOS-939, kut. 1, Zapisnik izvanredne sjednice Pododbora Matice hrvatske u Osijeku, 14. studenoga 1936., 1-2.

${ }^{49}$ HR-DAOS-939, kut. 1, Dopis Hrvatskoga akademskog kulturnog društva Ante Starčević Pododboru Matice hrvatske u Osijeku, 9. siječnja 1937. Upravu Hrvatskoga akademskog kulturnog društva Ante Starčević u Osijeku činili su predsjednik Stjepan Bunjevac (njegovo se ime kasnije nalazi u popisu podupirućih članova Pododbora MH Osijek), drugi predsjednik Zdenko Blažeković (njegov brat Milan Blažeković je član odbornik Pododbora MH Osijek i kasniji predsjednik Pododbora MH Osijek) te tajnik Franjo Gašparović.

${ }^{50}$ HR-DAOS-939, kut. 1, Dopis Franje Lukca predsjedniku Pododbora Matice hrvatske u Osijeku, 16. veljače 1937. 
kontekst postupnoga razmimoilaženja te kasnijih otvorenih ideoloških sukoba između MH i HSS-a, koji će eskalirati nakon uspostave Banovine Hrvatske. Njihovu genezu moguće je promatrati upravo negdje od početka 1936., kada su postali vidljiviji nakon Lukasova predavanja u Čakovcu, ${ }^{51}$ pa sve do vrhunca 1941., kada je u MH uvedena prisilna uprava i komesarijat. ${ }^{52}$ Ukratko, iz redova HSS-a zamjerao se MH pretjeran intelektualizam, odnarođenost i etnocentrizam, dok se HSS-u iz redova MH zamjerao populizam, pretjeran politički oportunizam, kolebljivost i zbližavanje s drugim južnoslavenskim (posebice srpskim) opozicijskim snagama. Zahvaljujući ovakvim pojedinačnim dokumentima, moguće je pratiti razvoj tih procesa na lokalnoj razini, a razvidno je da se ideološki sukobi između MH i HSS-a reflektiraju i prenose na razinu pododbora, o čemu svjedoči navedeni osječki slučaj. Lukac kasnije u NDH obnaša visoke dužnosti unutar Ustaške vojnice, što se također može pozicionirati u navedenom kontekstu te linearno pridodati njegovom istupanju iz MH, s navedenim obrazloženjem.

Četvrta sjednica predsjedničkoga vijeća osječkoga pododbora MH održana je 12. ožujka 1937. u prostorijama uprave Hrvatskog lista u Osijeku. Zanimljivo, kao i na prvoj sjednici predsjedničkoga vijeća, i na ovoj je, uz ispriku, izostao Pavišić, no prisutan je bio Mišo Mazur, kao tajnik omladinske sekcije. ${ }^{53}$ Pavetić je izvijestio o prodaji knjiga u proteklom razdoblju, predloživši isplatu honorara od 150 dinara Mazuru, koji je bio osobito aktivan po tom pitanju, što je jednoglasno usvojeno. Također, izvijestio je o skupštini MH u Zagrebu, kojoj je prisustvovao, podnoseći izvještaj o radu osječkoga pododbora, te je istaknuo da će mjesečni izvještaji o radu pododbora ubuduće biti objavljivani u Hrvatskoj reviji. ${ }^{54} \mathrm{Na}$ dnevnom redu bilo je i čitanje dopisa Hrvatskoga radiše (o predavanju koje će Zvonko Šprajcer održati 17. ožujka 1937.), HAKD Ante Starčević (o konstituiranju odbora u Osijeku), Pododbora MH u Varaždinu (o

${ }^{51}$ Predsjednik MH Filip Lukas održao je u veljači 1936. predavanje u Čakovcu, na kojem je istaknuo sljedeće: „Tako se piše ne samo s druge strane - koja bi htjela našu borbu iskriviti - nego i sa strane nekih tobožnjih naših ideologa, koji - bez poznavanja psiholoških i socioloških načela, na kojima se gradi narodna zajednica - tvrde da su naši seljaci - već po tome što su seljaci - bliži srpskim seljacima, nego našoj inteligenciji.“ Vidi: Damjanović, Matica hrvatska od 1842. do 2017., 136.

${ }^{52}$ Komesarijat je bio na snazi od 11. siječnja 1941. do 11. travnja 1941. Više: Filip Hameršak, „Komesarijat u Matici hrvatskoj“, Časopis za suvremenu povijest 35 (2003), br. 3, 835-859.

${ }^{53}$ Očito da je omladinska sekcija u međuvremenu utemeljena pa je tako, uz literarnu i propagandnu sekciju, postala treća organizirana sekcija osječkoga pododbora $\mathrm{MH}$, kojoj je, kao i literarnoj, na čelu bio Matija Kovačić, dok je Mišo Mazur obavljao dužnost tajnika.

${ }^{54}$ Hrvatska revija, književni časopis, izlazio mjesečno u Zagrebu 1928. - 1945. kao glasilo MH. Prvih godina u njemu su surađivali pisci različitih političkih i estetskih usmjerenja, a od 1933. izrazitije se priklanja političkoj desnici. Časopis pod istim imenom izdavali su od 1951. hrvatski intelektualci u emigraciji, a nakon uspostave Republike Hrvatske nastavila je izlaziti u Zagrebu kao časopis MH. 
izboru novoga odbora), Franje Lukca (o ostavci i istupanju iz MH) te Jovana Gojkovića ${ }^{55}$ (s prijedlogom da u zamjenu za svoje klišeje ${ }^{56} \mathrm{u}$ vrijednosti od 500 dinara, poslane u središnjicu MH, od osječkoga pododbora kao protuvrijednost dobije knjigu Ljube Babića ${ }^{57}$ Umjetnost kod Hrvata u XIX stoljeću). Taj je Gojkovićev prijedlog prihvaćen od strane Pododbora MH Osijek te je odlučeno da će se uputiti dopis ${ }^{58}$ zagrebačkoj središnjici MH. Mazur je podnio izvještaj o stanju i prodaji knjiga pristiglih iz Zagreba tijekom 1936., iz čega proizlazi da su od ukupno 1593 poslane knjige, od čega tri različita naslova, prodana ukupno 332 primjerka. Osim toga, Mazur je dao svoje viđenje stanja u omladinskoj sekciji, napominjući da je na sastanke dolazilo do 20 mladih te da je i Hrvatsko kulturno društvo Napredak ${ }^{59}$ (dalje: HKD Napredak) osnovalo svoju omladinsku sekciju, čije se članstvo uglavnom sastoji od istih osoba. Pododbor se složio da bi početkom travnja 1937. svoje predavanje o bunjevačkim Hrvatima trebao održati Petar Pekić ${ }^{60}$ iz Subotice, a zaključeno je da će se sjednica proširenoga pododbora sazvati 22. ožujka 1937., dok će se redovita godišnja skupština održati 5. travnja 1937. u 20 h u gornjogradskom Hrvatskom domu. Na koncu, Kozmar je podnio financijski izvještaj, iz kojega proizlazi da osječki pododbor MH ima pozitivnu bilancu od 2087,40 dinara, s obzirom na to da su prihodi iznosili 11.076,65 dinara, a rashodi 8989,25 dinara. ${ }^{61}$

Stanje u omladinskoj sekciji najslikovitije dočarava Mazurov dopis, koji nije datiran, no očito je Pododboru MH Osijek upućen prije četvrte sjedni-

${ }^{55}$ Jovan Gojković (1898. - 1957.), slikar. Rođen u Beču, najveći dio života proveo u Osijeku.

${ }^{56}$ Kliše (klišej) u likovnoj umjetnosti označava negativ prenesen na metalnu ploču s koje se tiska, odnosno matricu za umnažanje reprodukcija.

${ }^{57}$ Ljubo Babić (1890. - 1974.), hrvatski slikar i povjesničar umjetnosti. Završio Akademiju u Münchenu i Filozofski fakultet u Zagrebu, gdje je 1915. u svojemu atelijeru otvorio Modernu slikarsku školu, a potom više od četiri desetljeća predavao na zagrebačkoj Akademiji. Član grupe Medulić, suosnivač Grupe trojice. Jedan od najznačajnijih hrvatskih slikara portreta, krajolika, mrtvih priroda i figuralnih kompozicija.

${ }^{58}$ Dopis je zaista upućen 22. ožujka 1937., potpisan od Pavetića i Helfricha. HR-DAOS-939, kut. 1, Dopis Pododbora Matice hrvatske u Osijeku središnjici Matice hrvatske u Zagrebu, 22. ožujka 1937.

${ }^{59}$ HKD Napredak, hrvatsko kulturno društvo u BiH. Osnovano u Sarajevu 1902. kao društvo za pomoć učenicima. Do Drugoga svjetskog rata razvio se u najvažnije hrvatsko kulturnoprosvjetno društvo u $\mathrm{BiH}$ pa je tako 1912. u Sarajevu izgrađena palača društva, a u njegovu sklopu osnovani su zadruga, štedionica, niz knjižnica i učeničkih domova, dok se društvo bavilo i izdavaštvom. Društvu je 1949. zabranjen rad. Obnovljeno je u Sarajevu 1990.

${ }^{60}$ Petar Pekić (1896. - 1965.), publicist i književnik. Od 1918. živio i djelovao u Subotici, a 1937. preselio se u Zagreb. Publicističko-povijesne priloge o bačkim Hrvatima objavljivao je u subotičkom hrvatskom tisku te u Jutarnjem listu i Obzoru. Pisao je poeziju, prozu i povijesne rasprave te studije iz prošlosti Vojvodine i vojvođanskih Hrvata.

${ }^{61}$ HR-DAOS-939, kut. 1, Zapisnik IV. sjednice predsjedničkoga vijeća Pododbora Matice hrvatske u Osijeku, 12. ožujka 1937., 1-4. 
ce predsjedničkoga vijeća, u drugoj polovici 1936. ili početkom 1937. Ondje Mazur govori o 20-ak aktivnih članova te izriče pohvale pročelniku sekcije Kovačiću za trud i angažman u radu s mladima, istodobno se žaleći na nedovoljan angažman mladih. Mazur tako navodi „da jedan srednjoškolac radije voli ići na ples, zabavu, kino, kazalište ili „hofiranje“, nego li na jedan sastanak“. Na koncu predlaže izdavanje lista ili almanaha s radovima članova omladinske sekcije. ${ }^{62}$

Treća sjednica Pododbora MH Osijek održana je 22. ožujka 1937. u gornjogradskom Hrvatskom domu, a uz isprike su bili odsutni Kovačić, Pavišić, Blažeković i Rohregger. Dobar dio zaključaka s prethodne sjednice predsjedničkoga vijeća stavljen je na znanje, a pročitani su i zapisnici s prethodnih sjednica predsjedničkoga vijeća i pododbora (13. svibnja 1936., 25. rujna 1936., 14. studenoga 1936., 20. studenoga 1936. i 12. ožujka 1937.). Usvojen je prijedlog da se predavanja u omladinskim sekcijama Pododbora MH Osijek i osječkoga HKD Napretka odvijaju koordinirano i naizmjence, o čemu će se pobrinuti Köhler, predsjednik osječke podružnice HKD Napretka, ujedno i član odbornik osječkoga pododbora MH. Kozmar je obavijestio o prikupljenim članarinama tijekom 1936., dajući prijedlog da se ubuduće članarina ubire tromjesečno po pet dinara, što je i usvojeno. Uslijed Kovačićeva izostanka, predsjednik Pavetić dao je izvještaj o omladinskoj sekciji, naglasivši da je prosječan broj prisutnih na predavanjima $u$ organizaciji omladinske sekcije 13. Tajnik Helfrich iščitao je prijedlog izmjena poslovnika, koje su također usvojene, s namjerom da budu upućene i redovitoj glavnoj godišnjoj skupštini. Izneseno je da su do sada u organizaciji osječkoga pododbora MH održana četiri predavanja (Mile Starčević, Rudolf Herceg, Franjo Fancev ${ }^{63}$ i Filip Lukas), dok su za buduće razdoblje kao mogući predavači najavljeni Petar Pekić, Matija Kovačić, Josip Bösendorfer ${ }^{64}$ i Ante Vrgoč. ${ }^{65}$ Osim toga, taksativno su nabrojani svi članovi koji su do toga trenutka pristupili osječkom pododboru

${ }^{62}$ HR-DAOS-939, kut. 1, Dopis Miše Mazura Pododboru Matice hrvatske u Osijeku.

${ }^{63}$ Franjo Fancev (1882. - 1943.), knjižničar, filolog i književni povjesničar. Studirao slavistiku i romanistiku u Zagrebu i Beču, gdje je 1907. i doktorirao. Od 1908. knjižničar, a 1919. 1927. ravnatelj Sveučilišne knjižnice u Zagrebu, koju je profilirao kao nacionalnu i sveučilišnu ustanovu za duže razdoblje. Od 1926. profesor starije hrvatske književnosti na zagrebačkome Filozofskom fakultetu, a 1937. - 1939. predsjednik Društva hrvatskih književnika.

${ }^{64}$ Josip Bösendorfer (1876. - 1957.), povjesničar. Studij povijesti i zemljopisa započeo u Zagrebu, ali ga je zbog sudjelovanja u spaljivanju mađarske zastave 1895. morao nastaviti u Grazu, Beču i Pragu. Doktorirao u Zagrebu 1899. Kao gimnazijski profesor radio je u Zagrebu i Osijeku, a kao upravitelj osječke gimnazije 1917. - 1922. Preuzeo zbirke osječkoga Gradskog muzeja 1941., a 1946. preselio ga u prostorije u Tvrđi, te bio njegovim ravnateljem do 1949.

${ }^{65}$ Antun Vrgoč (1881. - 1949.), farmaceut. Doktor znanosti, profesor farmakognozije na Farmaceutskom fakultetu Sveučilišta u Zagrebu 1924. - 1945. 
$\mathrm{MH}$, njih ukupno $86 .{ }^{66} \mathrm{Na}$ koncu, zaključeno je da će se redovita glavna godišnja skupština održati prema planu, 11. travnja, te da će članovi o tome biti obaviješteni putem Hrvatskoga lista.$^{67}$

Izvještaj glavnoj skupštini Pododbora MH Osijek podnio je tajnik Helfrich, navevši 86 primljenih članova te posebno istaknuvši uspješnu suradnju s Hrvatskim listom i organizaciju gostovanja predsjednika MH Lukasa, s prigodnim popratnim predavanjem. ${ }^{68}$

Službeni dopis Pododbora MH Osijek upućen je i gornjogradskom Hrvatskom domu 5. travnja 1937., sa zamolbom za korištenje velike dvorane u svrhu održavanja redovite glavne godišnje skupštine, prema prethodnoj najavi. ${ }^{69}$

Tablica 2. Podupirući članovi Pododbora MH Osijek 1937.70

\begin{tabular}{|l|l|}
\hline Ime i prezime & Zanimanje \\
\hline Antolović, Marko & profesor \\
\hline Aničić, Ivan & trgovac \\
\hline dr. Batori, Julije & primarijus liječnik \\
\hline Beisman, Andrija & fotograf \\
\hline dr. Beljan, Tomislav & tajnik Trgovinske komore \\
\hline Blažeković, Milan & prokurist \\
\hline dr. Bösendorfer, Josip & profesor u mirovini \\
\hline ing. Bartolović, Adrijan & inženjer \\
\hline Bunjevac, Stjepan & veterinar \\
\hline Baraković, Lujo & privatni činovnik \\
\hline Crnković, Josip & gruntovničar \\
\hline dr. Cepelić, Iso & odvjetnik \\
\hline dr. Čačinović, Milan & liječnik \\
\hline dr. Ditz, Erih & liječnik \\
\hline Dogan, Zvonimir & gradski činovnik \\
\hline Ebner, Stanko & gradski činovnik \\
\hline
\end{tabular}

${ }^{66}$ Unutar fonda Pododbor MH Osijek u DAOS-u postoji i zaseban dokument, u kojem je poimence navedeno 88 članova (ovom popisu pridodani su Ernest Fišer i Josip Straus), iz čega je moguće promatrati strukturu članstva.

${ }^{67}$ HR-DAOS-939, kut. 1, Zapisnik III. sjednice Pododbora Matice hrvatske u Osijeku, 22. ožujka 1937., 1-4.

${ }^{68}$ HR-DAOS-939, kut. 1, Izvještaj tajnika Pododbora Matice hrvatske u Osijeku glavnoj skupštini Pododbora Matice hrvatske u Osijeku, 11. travnja 1937.

${ }^{69}$ HR-DAOS-939, kut. 1, Dopis Pododbora Matice hrvatske u Osijeku Hrvatskom domu u Osijeku, 5. travnja 1937.

${ }^{70}$ HR-DAOS-939, kut. 1, Popis podupirućih članova Pododbora Matice hrvatske u Osijeku. 


\begin{tabular}{|c|c|}
\hline Engelhardt, Dragutin & industrijalac \\
\hline Fabijanović, Ante & činovnik gradske štedionice \\
\hline dr. Firinger, Kamilo & odvjetnik \\
\hline dr. Fišer, Pavao & odvjetnik \\
\hline dr. Fišer, Ernest & odvjetnik \\
\hline mr. Fišter, Milan & ljekarnik \\
\hline ing. Franjetić, Radoslav & inženjer \\
\hline Frank, l. i dr. & veletrgovina \\
\hline Gottschalk, Hugo & državni činovnik u mirovini \\
\hline mr. Grabarić, Vladoje & ljekarnik suradnik \\
\hline Hećimović, Aleksandar & sudski savjetnik u mirovini \\
\hline mr. Helfrich, Franjo & provizor ljekarne \\
\hline dr. Hefer, Stjepan & odvjetnik \\
\hline dr. Hengl, Vjekoslav & kraljevski javni bilježnik \\
\hline Herman, Vilim & trgovac \\
\hline Horvatić, Josip & ravnatelj \\
\hline Hrabal, Josip & bankovni činovnik \\
\hline Hržić, Antun & gradski senator \\
\hline dr. Hurm, Antun & profesor \\
\hline Kozmar, Vatroslav & gradski savjetnik \\
\hline Kamnikar, Josip & profesor \\
\hline Koler, Franjo & obrtnik \\
\hline Kovačić, Matija & novinar \\
\hline ing. Köhler, Karlo & inženjer \\
\hline Krvarić, Kamilo & ravnatelj Hrvatskog lista \\
\hline Kovačević, Slavko & privatni činovnik \\
\hline Kornburger, Ferdo & privatni činovnik \\
\hline Kuzmanović, Koloman & Činovnik \\
\hline dr. Leitner, Marko & odvjetnik \\
\hline Leović, Josip & profesor \\
\hline Lakšteter, Josip & ekonom \\
\hline Mandić, Antun & željezničarski činovnik \\
\hline Martinović, Boris & učenik \\
\hline Mrkvička, Josip & bankovni činovnik \\
\hline Mrljak, Branko & frizer \\
\hline ing. Mudrovčić, Dragoljub & inženjer \\
\hline Muk, Dragan & ravnatelj gradske štedionice \\
\hline Mioković, Đuro & trgovac \\
\hline
\end{tabular}




\begin{tabular}{|c|c|}
\hline dr. Matijević, Zlatko & odvjetnik \\
\hline Mrljak, Vladimir & ravnatelj Napretkove zadruge \\
\hline dr. Nevidal, August & liječnik \\
\hline Narančić, Zorislav & činovnik \\
\hline Olrom, Franjo & geodet \\
\hline Opravić, Ivan & privatni činovnik \\
\hline Paradeiser, Ivan & učenik \\
\hline Pavetić, Tomislav & profesor \\
\hline Perković, Đuro & činovnik \\
\hline dr. Petrović, August & odvjetnik \\
\hline Piller, Ladislav & industrijalac \\
\hline Palić, Zdenka & učenica \\
\hline Pavišić, Josip & urednik Hrvatskog lista \\
\hline Rohregger, Lavoslav & trgovac \\
\hline dr. Rutar, Ante & liječnik \\
\hline Silberbauer, Franjo & učitelj \\
\hline Sip, Ivan & učitelj \\
\hline Spreitzer, Josip & činovnik \\
\hline Stanković, Ante & privatni činovnik \\
\hline Šeb, Jakob & vjeroučitelj, profesor \\
\hline Škuljević, Dragan & prokurist \\
\hline Šokičić, Josip & vjeroučitelj, profesor \\
\hline Straus, Josip & profesor \\
\hline Schwalm, Mica & kućanica \\
\hline ing. Steiner, Franjo & inženjer \\
\hline Sudarević, Franjo & ravnatelj, učitelj u mirovini \\
\hline Trbojević, Mirko & gradski činovnik \\
\hline Trenc, Pavao & gradski savjetnik \\
\hline Ugljenović, Milenko & student \\
\hline Verlić, Milan & profesor \\
\hline Vice, Ljudevit & ravnatelj u mirovini \\
\hline Vidaković, Armin & profesor \\
\hline Zatluka, Zlata & profesorica \\
\hline ing. Zimmer, Matija & ekonom \\
\hline
\end{tabular}

$\mathrm{Na}$ ovom popisu od 88 ljudi nisu navedena imena nekih članova odbornika osječkoga pododbora MH iz 1936. (Nikola Butković i Josipa Glembay, iako je Butković bio prisutan baš na sjednici 22. ožujka 1937). Isto tako, nema 
ni nekih istaknutijih članova omladinske sekcije (Mišo Mazur). Ukoliko bismo i njih pridodali ovom popisu, došli bismo do ukupne brojke od 91 člana Pododbora MH Osijek 1937. Spolna struktura članstva izrazito je muška, jer se među članovima nalaze tek četiri žene (Josipa Glembay, Zdenka Palić, ${ }^{71}$ Mica Schwalm i Zlata Zatluka). Dobna struktura ponajviše naginje zrelijem i starijem članstvu, dok izuzetak od pravila predstavljaju troje učenika (Boris Martinović, Ivan Paradeiser i Zdenka Palić) i jedan student (Milenko Ugljenović). Što se tiče obrazovne strukture, ona je nešto raznovrsnija, no najveći dio članstva ipak je visokoobrazovan (odvjetnici, liječnici, srednjoškolski profesori, inženjeri itd.) ili srednjeobrazovan (činovnici, ekonomi, prokuristi itd.), uz izuzetak nekolicine trgovaca, obrtnika, učenika itd.

Iz svega navedenoga vidi se da je osječki pododbor MH 1936. i 1937. imao iznimno dobar kadrovski potencijal te je sukladno tome bio primjereno organizacijski posložen i vrlo aktivan u kulturnoj i intelektualnoj domeni na lokalnoj razini. Kontakti, koordinacija i suradnja s ostalim kulturnim društvima bili su uobičajene pojave, s obzirom na niz vrlo utjecajnih članova, koji su bili aktivni i u drugim organizacijama. To se posebice odnosilo na društva $\mathrm{s}$ hrvatskim predznakom, $\mathrm{u}$ prvom redu Hrvatski dom, ${ }^{72}$ Hrvatsku ženu, ${ }^{73}$ Hrvatskoga radišu, ${ }^{74}$ HAKD Ante Starčević ${ }^{75}$ i HKD Napredak ${ }^{76}$ s kojima je suradnja očita, a u narednom se razdoblju vjerojatno ostvarila i s organizacijom Hrvatski junak, ${ }^{77} \mathrm{~s}$ obzirom na rukovodeću strukturu toga društva. Uz to, istaknuti članovi osječkoga pododbora $\mathrm{MH}$ istovremeno su bili utjecajni na kulturnom (fotograf Andrija Beisman; povjesničar i muzealac Josip Bösendorfer; arhivist, športski djelatnik i povjesničar Kamilo Firinger;

${ }^{71}$ Zdenka Palić, supruga Jakše Kušana, od 1945. u iseljeništvu, najprije u logoru Fermo u Italiji, a kasnije u Londonu.

${ }^{72}$ Milan Čačinović, član odbornik Pododbora MH Osijek, bio je predsjednik Odbora za gradnju Hrvatskoga doma.

${ }^{73}$ Josipa Glembay istovremeno je članica odbornica Pododbora MH Osijek i predsjednica osječke podružnice Hrvatske žene.

${ }^{74}$ Aleksandar Hećimović, potpredsjednik Pododbora MH Osijek, neko je vrijeme bio predsjednik osječke podružnice Hrvatskoga radiše.

${ }^{75}$ Stjepan Bunjevac istovremeno je podupirući član Pododbora MH Osijek i predsjednik osječkoga HAKD Ante Starčević.

${ }^{76}$ Vladimir Mrljak istovremeno je član odbornik Pododbora MH Osijek i ravnatelj Naprekove zadruge, a u ranijem je razdoblju bio i vođa osječkoga Hrvatskog sokola.

${ }^{77}$ Hrvatski junak, organizacija koja je djelovala između 1939. i 1941. kao baštinica tradicije Hrvatskoga sokola, prisilno ugašenoga 1929. Primjetno je da su mnogi članovi Hrvatskoga junaka kasnije bili na istaknutim položajima u NDH. Prema prikupljenim podatcima, Hrvatski junak na osječkom području djelovao je 1940. - 1941., a starješina mu je bio Stjepan Hefer, član odbornik Pododbora MH Osijek 1936. - 1937., dok je zamjenik starješine bio Franjo Helfrich, tajnik Pododbora MH Osijek 1936. - 1937. Vidi: Uredništvo, „Glavna skupština Hrv. Junaka“, Hrvatski list, Osijek, 27. siječnja 1941. 
slikar, kipar i grafičar Josip Leović; književnik i prosvjetni djelatnik Franjo Sudarević; predsjednik pjevačkoga društva Lipa Stjepan Hefer; predsjednik Hrvatske pjevačke župe Kuhač Ljudevit Vice), političkom (Stjepan Hefer, narodni zastupnik Hrvatske seljačke stranke u Narodnoj skupštini Kraljevine Jugoslavije u Beogradu, izabran na izborima 1935. i 1938; Vjekoslav Hengl, gradonačelnik Osijeka 1920. - 1934. ispred Hrvatske zajednice ${ }^{78}$ i Hrvatske federalističke seljačke stranke) ${ }^{79}$ gospodarskom (Milan Blažeković, prokurist Prvoga hrvatsko-slavonskog dioničkog društva za industriju šećera u Osijeku; Ladislav Piller, ${ }^{80}$ sin osnivača Karoline tvornice keksa, bombona i tjestenine d. d. Osijek), medijskom (Matija Kovačić, novinar Hrvatskog lista; Kamilo Krvarić, ravnatelj Hrvatskog lista; Josip Pavišić, urednik Hrvatskog lista) i vjerskom polju (profesori vjeroučitelji Jakob Šeb i Josip Šokičić).

O aktivnostima Pododbora MH u Osijeku 1936. i 1937. svjedoči i pozamašan broj sačuvanih novinskih izrezaka, uglavnom iz Hrvatskog lista te jedan iz Hrvatskog dnevnika ${ }^{81}$ koji se nalaze u fondu Pododbor Matice hrvatske Osijek u DAOS. Također, osobni fond Stjepana Hefera krije jednu zanimljivost vezanu uz osječki pododbor MH. Naime, riječ je o markicama za članarinu, koje se nalaze u jednoj plastičnoj vrećici, uz niz Heferovih članskih iskaznica, pozivnica i sl. Iz tih je markica vidljivo da se članarina naplaćivala po tromjesečju, odnosno četvrti godine, te da je iznosila 5 dinara. ${ }^{82}$

${ }^{78}$ Hrvatska zajednica, politička stranka nastala 1919. Protivila se centralizmu Kraljevine SHS, a okupljala je nekoliko starijih stranaka na čelu sa Starčevićevom strankom prava. Bila je članica tzv. prvoga i drugoga Hrvatskoga bloka.

${ }^{79}$ Hrvatska federalistička seljačka stranka, politička stranka nastala 1926. od Hrvatske zajednice i disidenata HSS-a. Osnovao ju je Ante Trumbić, a raspuštena je uvođenjem Šestosiječanjske diktature 1929.

${ }^{80}$ Ladislav Piller (1891. - 1960.), sin Stjepana Pillera, osnivača Karoline d. d. Vidi: Zlata Živaković-Kerže, Gabriela Dobsai, Karolina: od Pillerovog paromlinskog društva, Karoline, Slobode do Kraš grupe (Osijek, 2017), 35.

${ }^{81}$ Hrvatski dnevnik, dnevni list iz Zagreba. Počeo izlaziti 1936., a prestao u travnju 1941. Izravno vezan uz politiku HSS-a, u početku su ga uređivali Oton Pupić i Franjo Leaković, a kasnije Ilija Jakovljević.

${ }^{82}$ Državni arhiv u Osijeku, osobni fond Stjepana Hefera (dalje: HR-DAOS-1177), kut. 19, markice za članarinu u Pododboru Matice hrvatske u Osijeku. 
Tablica 3. Postotni udio i broj podupirućih članova Pododbora MH Osijek 1937. po zanimanju

\begin{tabular}{|l|c|c|}
\hline Zanimanje & Broj članova & Postotni udio \\
\hline činovnik & 17 & $19,32 \%$ \\
\hline profesor/učitelj & 15 & $17,05 \%$ \\
\hline odvjetnik & 8 & $9,09 \%$ \\
\hline inženjer & 5 & $5,68 \%$ \\
\hline liječnik & 5 & $5,68 \%$ \\
\hline trgovac & 4 & $4,55 \%$ \\
\hline ljekarnik & 3 & $3,41 \%$ \\
\hline učenik & 3 & $3,41 \%$ \\
\hline ekonom & 2 & $2,27 \%$ \\
\hline prokurist & 2 & $2,27 \%$ \\
\hline industrijalac & 2 & $2,27 \%$ \\
\hline ostala zanimanja & 22 & $25 \%$ \\
\hline
\end{tabular}

Grafički prikaz 1. Članovi Pododbora MH Osijek prema spolu

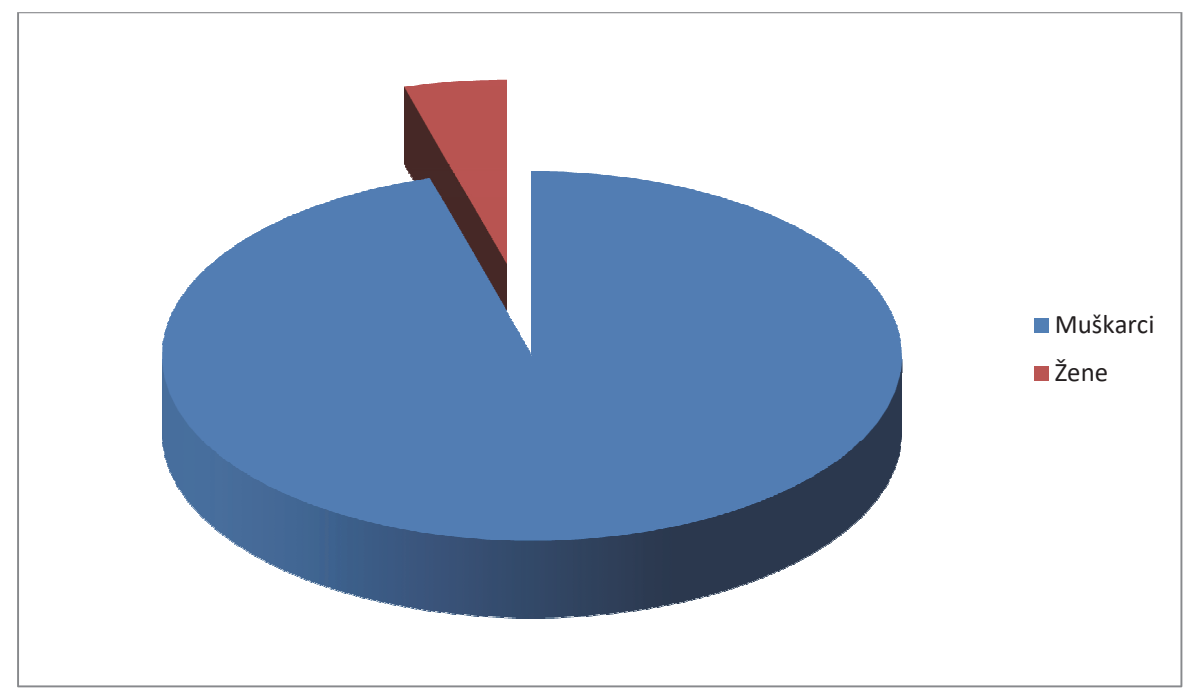


Grafički prikaz 2. Članovi Pododbora MH Osijek prema zanimanju



Vrijedi spomenuti da je, sukladno odluci MH o potrebi proširenja svoje mreže pododbora, njihovo osnivanje na području istočne Slavonije $u$ drugoj polovici 30-ih godina 20. st. zahvatilo i druga važnija središta, poput Vinkovaca i Vukovara. Primjerice, vukovarski pododbor MH osnovan je početkom 1939., o čemu su pisale Srijemske novine i Srijemski Hrvat. ${ }^{83}$

\section{Hrvatski sjever i njegovi suradnici}

S obzirom na ranije spomenuti nedostatak izvorne građe, što se odnosi i na razdoblje Banovine Hrvatske (1939. - 1941.) i na razdoblje NDH (1941. - 1945.), znatno je teže ulaziti u dublje raščlambe djelovanja Pododbora MH Osijek u tom intervalu. Međutim, preko sačuvanih fragmenata građe te posebice časopisa Hrvatski sjever, moguće je dobiti opću sliku stanja u osječkom pododboru MH.

Prvi predsjednik Pododbora MH Osijek Tomislav Pavetić umire 4. srpnja $1940 .,{ }^{84}$ no nije poznato tko i kada ga na toj dužnosti nasljeđuje. Također, umi-

${ }^{83}$ Više: Vlado Horvat, Vukovarska društva (1859. - 1945.) (Vukovar, 2007), 103-104; Štefica Šarčević, „Napokon Matica hrvatska u Vukovaru“, u: Dražen Živić, Ivana Žebec, Vukovar hrvatska baština i perspektive razvoja (Zagreb, 2007), 465-470.

${ }^{84}$ Državni arhiv u Osijeku, fond Realne gimnazije (dalje: HR-DAOS-158), dokument br. 61303 - II, 1940., Dopis Glavnom banovinskom računskom uredu, 22. srpnja 1940. 
re i potpredsjednik Aleksandar Hećimović, godinu ranije, 1939. ${ }^{85}$ Međutim, pozdravni brzojav upućen Mili Budaku 23. travnja 1941., povodom njegova imenovanja na mjesto ministra prosvjete, otkriva da je tada predsjednik Pododbora MH Osijek bio Milan Blažeković, dok je Milan Ratković obnašao dužnost tajnika, ${ }^{86}$ iz čega slijedi da je Blažeković vrlo vjerojatno izabran na tu dužnost neposredno nakon Pavetićeve smrti, odnosno tijekom 1940.

Među fragmentima građe nalazi se i jedan zanimljiv dopis osječkom pododboru MH iz Donjeg Miholjca, datiran 31. srpnja 1944., u kojem zbog preopterećenosti poslom kotarski pristav ${ }^{87}$ odbija ponuđenu ulogu povjerenika $\mathrm{MH},{ }^{88}$ objašnjavajući da je ,ujedno i logornik“ te da ni te poslove ne stigne „redovno svršavati““. 89

Prvi broj časopisa Hrvatski sjever nije sačuvan u arhivi Ogranka MH u Osijeku, no moguće ga je pronaći u Nacionalnoj i sveučilišnoj knjižnici u Zagrebu. Objavljen je u srpnju 1944., s podnaslovom „književna i prosvjetna revija Pododbora Matice hrvatske u Osieku“. ${ }^{90}$ Cijena mu je bila $150 \mathrm{kn}$, a sadržavao je trinaest tekstova, uz rubriku „Ocjene i prikazi“ s deset priloga. Među tekstovima se mogu pronaći publicistički te književni (proza i poezija) tekstovi, dok se među ocjenama i prikazima nalaze književne i kazališne kritike te ocjene filozofskih naslova u izdanju MH (Albert Haler, ${ }^{91}$ Doživljaj ljepote, Zagreb, 1943.), kao i pregledi djelatnosti pojedinih osječkih kulturnih institucija, društava i medija.

U impressumu časopisa stoji da Hrvatski sjever ,,izlazi jedanput mjesečno“, što je prilično ambiciozno zamišljeno, čak i za mirnodopske prilike, a kao urednik je istaknut Josip Mirković. ${ }^{22}$

${ }^{85}$ Goran Ante Blažeković, „Zdenko Blažeković i njegova obitelj: žrtve Jugoslavije i komunizma“, Politički zatvorenik 19 (2011), 230, 37.

${ }^{86}$ Tomislav Jonjić - Stjepan Matković, Iz korespondencije dr. Mile Budaka (1907. - 1944.) (Zagreb, 2012), 316.

${ }^{87}$ Potpis nije do kraja čitak i jasan, no vrlo vjerojatno se radi o Nikoli Hećimoviću, sinu Aleksandra Hećimovića, koji je obnašao tu dužnost u vrijeme NDH. Više: Blažeković, „Zdenko Blažeković i njegova obitelj: žrtve Jugoslavije i komunizma“, 38.

${ }^{88}$ Ta mu je uloga ponuđena dopisom od 19. srpnja 1941., koji nažalost nije sačuvan.

${ }^{89}$ HR-DAOS-939, kut. 1, Dopis kotarskoga pristava u Donjem Miholjcu Pododboru Matice hrvatske u Osijeku, 31. srpnja 1944.

${ }^{0}$ Tada je na snazi bio korijenski pravopis pa stoga oblik Osieku, umjesto Osijeku.

${ }^{91}$ Albert Haler (1883. - 1945.), hrvatski estetičar, književni kritičar, povjesničar i teoretičar. Diplomirao klasičnu filologiju na Filozofskom fakultetu u Beču 1909., doktorirao u Zagrebu. Ubijen od partizana na Križnom putu nedaleko od Maribora 1945.

92 Josip Mirković (1906. - ?), svećenik i književnik. Rođen u Ruščici, Realnu gimnaziju pohađao u Slavonskom Brodu, a Nadbiskupsku klasičnu gimnaziju u Travniku. Bogosloviju završio u Đakovu, zaređen za svećenika 1930., a diplomirao na Bogoslovnom fakultetu u Zagrebu 
Među suradnicima prvoga broja su Josip Mirković, Martin Robotić, ${ }^{93}$ Josip Gunčević, ${ }^{44}$ Ante Jakšić, Milan Ivšić, ${ }^{95}$ Franjo Babić, ${ }^{96}$ Stjepan Perčević, Stipa Bačić, Mladen Kabalin, ${ }^{97}$ Stanko Vitković, ${ }^{98}$ Kamilo Krvarić, Kruno Stošić, Marinko Prepunić, ${ }^{99}$ Nikola Tadić i Kamilo Kolb ${ }^{100} \mathrm{~s}$ tekstovima te Rudolf Švagel-Lešić, Ivan Šimetić i Stjepan Macanić s crtežima.

U uredničkom uvodniku pod naslovom „Naš put“ Mirković na sljedeći način obrazlaže naziv časopisa i sažima cilj njegova pokretanja te sadržajne i prostorne smjernice djelovanja:

„(...) Možda će se tko pitati: zašto se naša revija zove baš 'Hrvatski sjever'. Odgovaramo:

1934. Obavljao dužnost kapelana u Srijemskoj Mitrovici i Slavonskom Brodu te župnika u Donjim Andrijevcima. Od 1937. u Osijeku kateheta na raznim školama. Objavio je zbirku pripovijedaka Kroz naše selo u Osijeku 1944. Više: Luka Marijanović, „Kulturno-prosvjetna i preporodna djelatnost profesora i studenata Đakovačke bogoslovije“, Diacovensia 4 (1996), 1, 130. Luka Marijanović navodi da je Mirković „ubijen 1945.“, kao i Anto Baković (Anto Baković, Hrvatski martirologij XX. stoljeća, Zagreb, 2007, 453), dok Vladimir Rem navodi da je „skončao na Bleiburgu 1945.“ (Vladimir Rem, „Postoji li šokačka književnost?“, Kolo XVIII (2008), 1). Antun Jarm pak navodi da je nestao (Antun Jarm, Pribrojeni zboru mučenika, Đakovo, 2007, 63). Ipak, recentna istraživanja Miroslava Akmadže i Slađane Josipović Batorek pokazuju da je to prilično dvojbeno, odnosno da je vjerojatnija varijanta prema kojoj je pobjegao u inozemstvo, o čemu govore i komunistički izvori, a tu je i njegov potpis na $\mathrm{Me}$ morandumu katoličke svećeničke emigracije predsjedniku SAD-a Dwightu D. Eisenhoweru iz 1954. Vidi: Miroslav Akmadža, Slađana Josipović Batorek, Stradanja svećenika Đakovačke i Srijemske biskupije 1944. - 1960. (Slavonski Brod - Đakovo, 2012), 11-12.

${ }^{93}$ Martin Robotić (1904. - 1968.), profesor i ravnatelj gimnazije u Županji.

94 Josip Gunčević (1895. - 1945.), publicist i pedagog. Zaređen za svećenika 1918., doktorirao na Teološkom fakultetu u Zagrebu 1928., od 1939. ravnatelj gimnazije u Slavonskom Brodu. Prilikom povlačenja pred partizanima 1945. ubijen u Maceljskoj šumi.

${ }^{95}$ Milan Ivšić (1887. - 1972.), hrvatski ekonomist i sociolog. Doktorirao u Parizu 1926., predavao sociologiju, socijalnu politiku i političku ekonomiju na Ekonomsko-komercijalnoj visokoj školi u Zagrebu do 1945.

${ }^{96}$ Franjo Babić (1908. - 1945.), književnik i novinar. Od 1929. novinar, a između 1941. i 1944. odgovorni urednik osječkoga Hrvatskog lista. Od 1944. novinar u Zagrebu, pri povlačenju iz NDH u svibnju 1945. ubijen od partizana u okolici Maribora.

${ }^{97}$ Mladen Kabalin (1915. - 1997.), pjesnik. Završio klasičnu gimnaziju u Zagrebu te diplomirao pravo 1938. Ravnatelj Državne krugovalne postaje Osijek 1944. - 1945., nakon 1945. djeluje u iseljeništvu.

98 Stanko Vitković (1913. - 1945.), pjesnik. Diplomirao francuski i njemački jezik na Filozofskom fakultetu u Zagrebu 1937. Za vrijeme NDH ravnatelj je na Nastavnom odjelu Ministarstva oružanih snaga. Vojni sud u Zagrebu osudio ga je na smrt 1945.

${ }^{99}$ Marinko Prepunić (1911. - 1975.), svećenik, profesor povijesti, hrvatske književnosti i filozofije.

${ }^{100}$ Kamilo (Stjepan) Kolb (1887. - 1965.), franjevac, skladatelj. Zaređen za svećenika 1910. aktivno djelovao u javnom i kulturnom životu Osijeka 1941. - 1944. Vojni sud Zagreba osudio ga 1945. na šest godina zatvorske kazne. 
Zato, što smo na sjevernoj granici hrvatske države;

zato, što želimo kulturno povezati i najsjevernije Hrvate izvan naših državnih granica;

zato, što smo htjeli zahvatiti za književnu obradbu i hrvatske krajeve, koji su izvan obsega uže Slavonije, a gravitiraju gradu Osijeku kao kulturnom središtu.

Nastojat ćemo da okupimo oko 'Hrvatskog sjevera' sve one kulturne radnike, koji potječu iz ovoga kraja ili na našem području djeluju u javnom životu. Svojim časopisom želimo omogućiti i mlađem pokoljenju, da se književno afirmira; tako ćemo nastaviti liepe tradicije hrvatsko-slavonske književnosti i udovoljiti suvremenim kulturnim potrebama slavonske Hrvatske.

Uredničtvo »Hrvatskog sjevera« očekuje od svojih suradnika ponajprije beletristične priloge (pjesme, crtice, novele) uzete iz narodnog života Slavonije, Sriema, Baranje i Bačke. Prednost dajemo umjetničkim obradbama sujeta sa sela, jer je slavonski Hrvat čvrsto povezan s rodnom grudom i veliki rodoljub.

Naša će revija u svakom broju objavljivati i prosvjetno-naučne članke, koji će udovoljavati potrebama našeg duševnog života. (...)“101

Drugi broj ${ }^{102}$ Hrvatskoga sjevera, sačuvan u arhivi Ogranka MH u Osijeku, objavljen je u kolovozu 1944. Sadržavao je dvanaest tekstova te rubriku „Ocjene i prikazi“, s tri priloga. Među tekstovima ima publicističkih i književnih (proza i poezija) tekstova, dok se među ocjenama i prikazima nalaze kritike književnih (drama i poezija) i teorijskih djela u izdanju MH (Rudolf Kjellén, ${ }^{103}$ Država kao oblik života, Zagreb, 1943).

\footnotetext{
${ }^{101}$ Josip Mirković, „Naš put“, Hrvatski sjever 1 (1944), 1, 2.

${ }^{102}$ Neki su ranije navodili kako je bila riječ o dvobroju (Damjanović, Matica hrvatska od 1842. do 2017., 156), no jasno je da ipak nije tako, s obzirom na to da sam pregledavao oba zasebna broja.

${ }^{103}$ Rudolf Kjellén (1864. - 1922.), švedski politolog i povjesničar. Smatra se osnivačem geopolitike, a geopolitika se smatra njegovom terminološkom inovacijom. Njegovu teoriju o potrebi jedne jedinstvene srednjoeuropske države, radi ravnoteže između Ujedinjenoga Kraljevstva, Rusije i Sjedinjenih Američkih Država, preuzela je i zlorabila njemačka politička teorija kako bi opravdala osvajačke interese njemačke vanjske politike. Kjellénovim djelom još prije uspostave NDH posebno je bio inspiriran Julije Makanec, kasniji ministar narodne prosvjete u vladi NDH, višestruko ga citirajući i pozivajući se na njega u svome djelu $O$ podrijetlu i smislu države iz 1939.
} 
Među suradnicima drugoga broja nalaze se Andrija Živković, ${ }^{104}$ Zdenka Jušić Seunik, ${ }^{105}$ Ivan Kovačić, Ante Jakšić, Mladen Kabalin, Mirko Držaić, Martin Robotić, Mišo Mazur, Franjo Babić, Šime Štampalija, Krunoslav Sip, Marinko Prepunić, Josip Mirković, Vladimir Jurčić, Dragutin Đurić i Milan Blažeković s tekstovima te Stjepan Macanić i Ivan Šimetić s crtežima.

Ukoliko promotrimo zavičajnu strukturu zastupljenih autora, većina njih rođeni su i djelovali na području Slavonije. Kao kuriozitet valja istaknuti činjenicu da se Robotić kao autor s prilogom pojavljuje u oba broja Hrvatskoga sjevera, ali i u prvom broju Revije, ${ }^{106}$ časopisa koji je pokrenuo obnovljeni Pododbor MH Osijek 1961. ${ }^{107}$ To je neobično jer je dobar dio intelektualnih djelatnika iz razdoblja NDH nakon Drugoga svjetskog rata bio u najmanju ruku ostraciziran iz javnoga života, ako već ne sustavno likvidiran, dok je drugi dio emigrirao, a primjeri poput Robotića zaista su rijetki.

Nakon Drugoga svjetskog rata $\mathrm{MH}$ je nastavila s radom s novim rukovodstvom, ponajviše kao nakladnička kuća, a nešto manje kao kulturno-prosvjetna institucija. Njezini pododbori pak nisu imali mogućnost nastavka djelovanja sve do 1953., premda je Joža Horvat ${ }^{108}$ davao prijedlog reorganizacije mreže pododbora još 1945 . Međutim, tada je vladao kruti politički i kulturni centralizam, koji je donekle olabavio udaljavanjem Jugoslavije i Sovjetskoga Saveza 1948. te smrću Josifa Visarionoviča Staljina 1953. ${ }^{109}$ Osim toga, mnogi su pododbori $\mathrm{MH}$, među koje možemo ubrojati i osječki, u vrijeme NDH dobar dio svojih istaknutih članova iznjedrili na utjecajne položaje unutar ustaškoga režima.

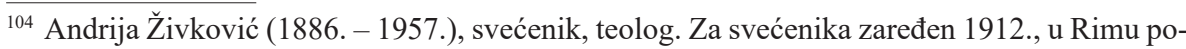
stigao doktorat iz filozofije i teologije. Postao redoviti profesor na Bogoslovnom fakultetu u Zagrebu. Obnašao službu dekana Bogoslovnog fakulteta i rektora Zagrebačkoga Sveučilišta 1939. - 1940.

${ }^{105}$ Zdenka Jušić Seunik (1905. - 1989.), književnica. Radila kao knjižničarka u Gradskoj knjižnici 1939. - 1943. i u Ministarstvu prosvjete 1943. - 1944. te kao korektorica u Društvu sv. Ćirila i Metoda 1945. - 1956. u Zagrebu. Surađivala u periodici pjesmama, novelama, romanima te člancima o književnosti i ženskom pokretu.

${ }^{106}$ Revija, časopis Pododbora/Ogranka MH Osijek, redovito izlazi 1961. - 1990. Od 1991. do danas nosi naziv Književna revija.

107 Više: Martin Robotić, „Jubilej života i smrti“, Revija 1 (1961), 19-22.

108 Joža Horvat (1915. - 2012.), hrvatski književnik, sudionik Drugoga svjetskog rata na strani Narodnooslobodilačke vojske i partizanskih odreda Jugoslavije.

109 Više: Tatjana Šarić, „Matica hrvatska u prvim poslijeratnim godinama (1945-1948)“, Arhivski vjesnik 54 (2011), 123-127. 
Do obnove rada osječkoga pododbora $\mathrm{MH}$ došlo je na inicijativu koja je pokrenuta 1960., a realizirana $1961 .{ }^{110}$ Međutim, inicijativa za obnovu njegova rada postojala je i ranije, javivši se još 1950-ih., kada su obnovljeni pododbori u Splitu (1953.) te Zadru, Rijeci i Dubrovniku (1954.). Tada je na čelu inicijative bio Lav Grisogono, ${ }^{111}$ urednik lista Slavonija danas ${ }^{112}$ no taj je pokušaj na koncu ipak ostao neuspješan, iako nije do kraja jasno što je presudilo tomu, s obzirom na nešto povoljnije političke okolnosti na saveznoj i republičkoj razini.

\section{Zaključna razmatranja}

MH kao jedna od stožernih hrvatskih kulturnih institucija djeluje i u dinamičnom razdoblju 30-ih i 40-ih godina 20. st., doduše u vrlo različitim političkim okolnostima. Sukladno tome, i njezini pododbori, kao temeljne organizacijske jedinice, nositelji su kulturnih aktivnosti na lokalnoj razini. Pododbor MH Osijek osnovan je u jeku širenja mreže pododbora MH 30-ih te je relativno brzo zauzeo važnu ulogu u oblikovanju kulturnoga života na području Osijeka. Do toga je došlo zbog ranijega ugleda i utjecaja koji je MH uživala među intelektualcima i kulturnim djelatnicima, ali ponajviše zbog toga što se u redove njezina osječkoga pododbora uključuje čitav niz utjecajnih članova, koji su godinama obnašali razne dužnosti na polju kulture, umjetnosti, obrazovanja, politike, gospodarstva i medija. Među njima napose treba istaknuti krug ljudi oko Hrvatskog lista, kao najutjecajnijih novina na hrvatskom jeziku u Osijeku, ali i na širem slavonskom području. Njihov je utjecaj na brz i lak način omogućio Pododboru MH Osijek javnu prepoznatljivost i vidljivost aktivnosti. Također, treba istaknuti i kontinuiranu snažnu potporu središnjice, koja se ogledala i u gostovanju predsjednika MH Filipa Lukasa, koji je u godini osnutka osječkoga pododbora (1936.) održao gostujuće predavanje u Osijeku.

Nažalost, nedostatak arhivskoga gradiva onemogućava dublji uvid u aktivnosti osječkoga pododbora MH između 1938. i 1945., no uz pojedine fragmente, kao supstitut izvornoj građi može poslužiti i časopis Hrvatski sjever iz 1944. Uvidom i analizom strukture njegovih suradnika, donekle je moguće rekonstruirati ulogu i položaj Pododbora MH Osijek u vrijeme NDH. Vidljivo je da su u tom razdoblju mnogi njezini istaknuti članovi iz 30-ih obnašali različite javne dužnosti, poput Stjepana Hefera (veliki župan Velike župe Baranja 1941. - 1942. te ministar seljačkoga gospodarstva i prehrane 1943.), Milana

${ }^{110}$ HR-DAOS-939, kut. 4, Zapisnik s osnivačke skupštine Pododbora Matice hrvatske u Osijeku, 8. siječnja 1961.

${ }^{111}$ Lav Grisogono (1884. - 1971.), profesor matematike i fizike u Splitu i Zadru.

112 Slavonija danas, list za kulturna i društvena pitanja koji je izlazio 1954. - 1955., a glavni urednik mu je bio Lav Grisogono. 
Blažekovića (gradonačelnik Osijeka tijekom dvaju mjeseci 1941., povjerenik Trgovinsko-veleobrtne komore u Osijeku i ustaški logornik za grad Osijek), Franje Helfricha (dogradonačelnik Osijeka 1942.), Kamila Krvarića (stožernik ustaškoga stožera za Veliku župu Baranja), Matije Kovačića (ravnatelj i glavni urednik dnevnoga lista Hrvatski narod 1941. - 1942., glavni ravnatelj Glavnoga ravnateljstva za promičbu 1942. - 1944. i savjetnik u Ministarstvu vanjskih poslova), Franje Lukca (ustaški pukovnik, glavar Glavnoga stožera Ustaške vojnice i zapovjednik redarstvene straže u Ustaškoj vojnici) te Miše Mazura (ustaški logornik za grad Osijek) i Karla Köhlera, koji su obavljali funkcije na lokalnoj razini. Drugi su pak, poput Kamila Firingera i Josipa Bösendorfera, u ratnom razdoblju nastavili sa svojom stručnom djelatnošću, obnašajući javne dužnosti i nakon Drugoga svjetskog rata.

U konačnici, zbog nepovoljnih političkih okolnosti nakon Drugoga svjetskog rata u Drugoj Jugoslaviji, a velikim dijelom i zbog aktivnosti istaknutih članova osječkoga pododbora $\mathrm{MH}$ u vrijeme $\mathrm{NDH}$, uvjeti za obnovu njegova rada stvoreni su tek početkom 60 -ih godina 20 . stoljeća.

\section{Izvori i literatura}

\section{Neobjavljeni izvori}

Državni arhiv u Osijeku

Fond Pododbora Matice hrvatske Valpovo (HR-DAOS-1414), kut. 1

Fond Pododbora Matice hrvatske Osijek (HR-DAOS-939), kut. 1 i kut. 4

Fond Realne gimnazije (HR-DAOS-158)

Osobni fond Stjepana Hefera (HR-DAOS-1177), kut. 19

\section{Literatura}

Novine

Hrvatski list, Osijek, 27. siječnja 1941.

Knjige i članci

Akmadža, Miroslav; Josipović Batorek, Slađana, Stradanja svećenika Đakovačke i Srijemske biskupije 1944. - 1960., Slavonski Brod - Đakovo, 2012.

Baković, Anto, Hrvatski martirologij XX. stoljeća, Zagreb, 2007.

Blažeković, Goran Ante, „Zdenko Blažeković i njegova obitelj: žrtve Jugoslavije i komunizma“, Politički zatvorenik, 19 (2011), 230, 37-39.

Damjanović, Stjepan, Matica hrvatska od 1842. do 2017. Kalendar rada i djelovanja, Zagreb, 2018. 
Dizdar, Zdravko - Grčić, Marko - Ravlić, Slaven - Stuparić, Darko (ur.), Tko je tko u NDH, Zagreb, 1997.

Hameršak, Filip, „Komesarijat u Matici hrvatskoj“, Časopis za suvremenu povijest 35 (2003), 3, 835-859.

Horvat, Vlado, Vukovarska društva (1859. - 1945.), Vukovar, 2007.

Jarm, Antun, Pribrojeni zboru mučenika, Đakovo, 2007.

Jonjić, Tomislav - Matković, Stjepan, Iz korespondencije dr. Mile Budaka (1907. 1944.), Zagreb, 2012.

Kljaić, Stipe, Nikada više Jugoslavija. Intelektualci i hrvatsko nacionalno pitanje (1929. - 1945.), Zagreb, 2017.

Kolar-Dimitrijević, Mira, „Ukinuće Bjelovarsko-križevačke županije i kako je to područje prošlo u vrijeme djelovanja Osječke i Zagrebačke oblasne skupštine 1927. i 1928. godine“, Radovi Zavoda za znanstvenoistraživački i umjetnički rad u Bjelovaru 2 (2008), 35-58.

Lončar, Ivana, „Udruga Hrvatska žena u Osijeku (1921. - 1943.)“, Scrinia Slavonica 11 (2011), 207-258.

Marijanović, Luka, „Kulturno-prosvjetna i preporodna djelatnost profesora i studenata Đakovačke bogoslovije“, Diacovensia 4 (1996), 1, 109-145.

Mirković, Josip, „Naš put“, Hrvatski sjever 1 (1944), 1, 1-2.

Rem, Vladimir, „Postoji li šokačka književnost?“, Kolo XVIII (2008), 1.

Robotić, Martin, „Jubilej života i smrti“, Revija 1 (1961), 19-22.

Sučić, Stjepan, „Ogranci kao žile kucavice Matice hrvatske“, Kolo XXVII (2017), 3, 116-134.

Šarčević, Štefica, „Napokon Matica hrvatska u Vukovaru“, u: Živić, Dražen - Žebec, Ivana (ur.), Vukovar - hrvatska baština i perspektive razvoja, Zagreb, 2007., 465-470.

Šarić, Tatjana, „Matica hrvatska u prvim poslijeratnim godinama (1945-1948)“, Arhivski vjesnik 54 (2011), 115-140.

Tomas, Domagoj, Apostolska administratura za sjevernu Slavoniju i Baranju (1923. - 1972.), Đakovo - Osijek, 2018.

Vuković, Barbara, „Kako preživjeti smjenu režima? Sudbina Folksdojčera na prostoru Hrvatske“, Lucius 14 (2016), 21, 175-190.

Živaković-Kerže, Zlata; Dobsai, Gabriela, Karolina: od Pillerovog paromlinskog društva, Karoline, Slobode do Kraš grupe, Osijek, 2017. 


\title{
Summary \\ THE SUBCOMMITTEE OF MATICA HRVATSKA IN OSIJEK IN 1936-1945
}

The subcommittee of Matica hrvatska in Osijek was founded in 1936 on the initiative of several active members and commissioners of Matica hrvatska in Osijek, among which Franjo Helfrich, Aleksander Hećimović and Matija Kovačić can be singled out. Grammar school teacher Tomislav Pavetić was elected president at the Constitutional Assembly. The membership structure has been analysed on the basis of available member lists. It has been possible to examine the very rich and propulsive cultural activities of the Subcommittee of Matica hrvatska in Osijek which gave it an important position within the framework of the social, cultural and intellectual network of interwar Osijek. The activities include the establishment of specialized divisions within the Subcommittee, meetings of members, public lectures with home and guest participants, the publication of thematic articles in Hrvatski list, the collaboration with related cultural and heritage institutions in the territory of the city of Osijek, the distribution and sale of publications of Matica hrvatska and so on. These activities continued until 1937; but for a serious review of the activities of the Subcommittee in the following years there is a lack of source materials.

However, apparently, even according to rather fragmentary sources, the Subcommittee of Matica hrvatska in Osijek continued its work during the time of World War II and the Independent State of Croatia. After Pavetić's death in 1940 Milan Blažeković became president and many notable members of the Subcommittee took office within the governmental and political apparatus of the newly established state (Stjepan Hefer, Milan Blažeković, Franjo Helfrich, Kamilo Krvarić, Matija Kovačević, Franjo Lukac, Mišo Mazur and Karlo Köhler) while others primarily pursued their professions (Kamilo Firinger and Josip Bösendorfer). During this period the Subcommittee issued in 1944 its own journal Hrvatski sjever (Croatian North) one of the two active journals of the Subcommittee of Matica hrvatska outside of Zagreb; however, it was issued in two numbers only.

Keywords: Matica hrvatska, subcommittee, Osijek, Kingdom of Yugoslavia, Independent State of Croatia, Hrvatski sjever (journal Croatian North)

(Translated by Mica Orban Kljajić)

\author{
Kontakt autora: \\ Doc. dr. sc. Domagoj Tomas \\ Filozofski fakultet, Lorenza Jägera 9, 31000 Osijek \\ e-mail: domagoj.tomas@gmail.com
}

